\title{
Yleistajuista fennistiikkaa kevyellä otteella
}

\author{
Ville Eloranta \& Jaakko Leino: Sanaiset \\ kansiot. Suomen kielen vaietut vaiheet. \\ Helsinki: Gaudeamus 2017. 240 s. ISBN 978- \\ 952-495-412-9.
}

Sanaiset kansiot on Jaakko Leinon ja Ville Elorannan julkaisema yleistajuinen fennistiikan eri haaroja tarkasteleva teos. Leino on Helsingin yliopiston suomen kielen professori ja Eloranta Helsingin Sanomien kielenhuollosta vastaava toimittaja. Heitä yhdistää suomen kielen lautakunnan jäsenyys. Takakansitekstin mukaan "Sanaiset kansiot jäljittää suomen kielen salaisia piirteitä ja tuo ne päivänvaloon". Teos on "tarkoitettu kielestä ja sen kummallisuuksista kiinnostuneille". Teoksen yhtenä innoittajana on toiminut itsenäisen Suomen satavuotisjuhlavuosi.

Teos koostuu 44 lyhyehköstä kirjoituksesta, jotka on jaettu viiteen eriteemaiseen osastoon: "Kieli kartalla", "Tekstejä maan ja taivaan väliltä, "Politiikkaa ja muita intohimoja", "Normien jäljillä, kieliopin kannoilla" sekä "Kieli virtaa ja kiertää". Aiheiden kirjo on laaja: on yleistä suomalaisugrilaista kielihistoriaa Volgan mutkasta lähtien, vanhoja ja uusia lainasanoja, Agricolaa ja muutakin kirjakielen historiaa mutta myös viimeaikaisia kielenhuollon merkkitapauksia englannin kieltä unohtamatta. Kirjoitukset muistuttavat sanomalehden kielikolumneja tai vaikkapa kieliaiheista blogia, mutta ne eivät ole aiemmin ilmestyneet missään.

Viime vuosina suurinta huomiota saanut kielenhuollon tapahtuma oli keväällä 2014, kun suomen kielen lautakunta väljensi suositusta alkaa-verbin infinitiivitäydennyksen muodosta. Se nosti valtavan mediamyrskyn. Noussutta kohua on kuvattu herkullisesti luvussa "Kun kielilautakunta alkoi taipumaan". Parhaimmillaan Leinon ja Elorannan teksti on- kin sekä viihdyttävää että sivistävää ja sujuvasti kirjoitettua. Toisinaan kaipaisi kuitenkin hiukan tarkkuutta, kun jotkin yksityiskohdat eivät ole ihan kohdallaan. Aiheet vellovat niin moniaalla, että nostan tässä esiin vain joitakin seikkoja.

Pariin kolmeen otteeseen teoksessa otetaan esiin kouluopetus, jolloin kommentoidaan sitä, mitä "koululaissukupolvi toisensa jälkeen" on joutunut tekemään (s. 29, 171, 181). Esimerkiksi "siitä [suomen kielen muoto-opillisesta kirjavuudesta] joutuu koululaissukupolvi toisensa jälkeen kärsimään opetellessaan taivutusmuotojen kummallisia nimiä" (s. 181). Mielestäni kielentutkijoiden ei pitäisi vähätellä omaa tieteenalaansa niin, että luulottelisivat alan käsitteiden ja niiden nimitysten opettelun olevan jotenkin ikävämpää kuin minkä tahansa muun alan käsitteiden. Kielen analysoinnissa tarvittavien käsitteiden ja niiden nimitysten opettelun ei luulisi olevan kummempaa kuin kemiassa alkuaineiden nimitysten harjoittelun, biologian mitokondrioiden, mitoosien ja meioosien opettelun, puhumattakaan matematiikan derivaatoista ja ekstrapoloinneista.

Teoksessa tulee useassa kohtaa esiin se kaikille tuttu ilmiö, että kielimuoto, joka poikkeaa hieman itselle tutuimmasta, aina jotenkin kutittelee nauruhermoja. Tämä pätee niin itselle outoihin murteisiin, hiukkasen vanhahtavaan tai todella vanhaan kirjoitettuun suomeen kuin lähisukukieliinkin. Tässä teoksessa aihe tulee esille viron ja suomen riskisanoja käsiteltäessä ("Etäällä naapurissa"), Gananderin Eläinden Tauti-Kirjaa ja Maan-Miehen Huone- ja KotiAptheekin ohjeita käsiteltäessä ("Paloviinaa ja eläintenhoitoa") sekä myös sellaisessa omapohjaisessa sanastossa, joka ei ole vakiintunut käyttöön ("Sormitietokoneen nousu ja tuho"). 
Sormitietokoneen ('tabletti') ohella tällaisia sanoja ovat esimerkiksi vapuri ('handsfree') ja kieppo ('roll-on-deodorantti'). Hilpeyttä herättävät myös käytöstä pois jääneet kielioppitermit, kuten sisäolento tai vajanto ("Triviaalia kielioppia"). Jos kuitenkin aivan neutraalisti tarkastelee suomenkielisiä sijojen nimityksiä, eivät ne nyt loppujen lopuksi sen koomisempia ole kuin vaikkapa sana puhelin tai tasavalta. Niiden ainoa heikkous on outous: ne eivät tunnu tutuilta sanoilta.

Kirjassa käsitellään myös sitä, miten suomen kielen runsaita taivutuskategorioita yritettiin aikanaan sovitella latinan kieliopin luokituksiin. Ongelmaksi muodostui, että suomessa sijamuotoja on paljon enemmän kuin latinassa. Ja, kuten tekijät huomauttavat, näin tehtiin muuten myös englannin kieliopin kohdalla. Siinä ongelma oli oikeastaan päinvastainen (s. 161), kun englannissa taivutuskategorioita oli vähemmän kuin latinassa.

Euroopan kielten pakottaminen latinan kieliopin kehikkoon johtui varmaankin loppujen lopuksi siitä, että latinan kieliopin sivistynyt lukija jo tunsi. Itse ajattelisin, että suomen kielen tai yhtä hyvin vaikkapa englannin kielen muotojen asettaminen latinan kehikkoon auttoi näitä kieliä opettelevaa ymmärtämään, mitä mikin muoto ainakin suurin piirtein ilmaisi. Kieliopit oli mitä ilmeisimmin laadittu kieltä opettelevien avuksi, ei tieteelliseksi kielen rakenteen kuvaukseksi.

Jotenkin yllättävä on luvun "Mikä oli kirjakielen isän äidinkieli?" pohdiskelu siitä, mitä tapahtuu "kansalliselle ja suomalaiskulttuuriselle itsetunnolle, jos huomataan, että suomen kirjakieli on alkujaan kaksikielisen luoma rakennelma?” (s. 109). Uumoillaan, että joille- kin voisi olla kova pala, jos ensimmäisen suomenkielisen aapisen tekijä osoittautuisi "rantaruotsalaiseksi". No, ehkä erään jo hallitusvastuusta poistuneen puolueen kannattajakunnalle olisikin, mutta muille varmaankaan ei. Ellei Agricola olisi ollut taitava polyglotti (niin suomen, ruotsin, saksan, latinan kuin kreikan taitaja), hän olisi tuskin kääntänyt yhtään mitään.

Mitään kovin ihmeellisiä salaisuuksia (tai "sanaisuuksia") asiantuntijalukija ei Elorannan ja Leinon teoksesta löydä, mutta vähemmän aihetta harrastanut varmasti kokee oivalluksia. Eniten uutta näkökulmaa antaa luvussa "Kirjakielen synnyn todelliset syyt" esiteltävä ItäSuomen yliopiston historian professori Jukka Korpelan väite, ettei suomen kirjakielen kehittämisessä 1500-luvusta alkaen ole ollut kyse kansan sivistämisestä vaan tiukemmasta vallanpitäjien otteesta kansaan: sitenhän voitiin paremmin lukea saarnastuolista paitsi Jumalan sanaa myös kuninkaallisia asetuksia. Tarkemmin ajateltuna tästä varmastikin oli kysymys. Toisaalta: kun yleiskieli on suomen kielelle saatu ja kun se on näihin päiviin asti säilynyt, kannattaa siitä pitää kiinni.

Kirjan lyhyet luvut jättävät monesti lukijan kaipaamaan lisätietoa. Siksi on hyvä, että teoksen lopussa on lyhyt kirjallisuusluettelo. Kaiken kaikkiaan teos on hyvä lisä yleistajuisten suomen kieltä käsittelevien kirjojen joukkoon. Sitä voi suositella kielestä ja sen kummallisuuksista kiinnostuneille taviksille.

$$
\begin{array}{r}
\text { MARI SIIROINEN } \\
\text { etunimi.sukunimi@helsinki.fi }
\end{array}
$$

Kirjoittaja on tutkimuskoordinaattori Helsingin yliopiston humanistisessa tiedekunnassa. 